\title{
Sildenafil-Mediated Neuroprotection from Adult to Neonatal Brain Injury: Evidence, Mechanisms, and Future Translation
}

\author{
Manuela Zinni ${ }^{1}$, Julien Pansiot ${ }^{1}$, Pierre-Louis Léger ${ }^{2}$, Marina El Kamouh ${ }^{1,3}$ and Olivier Baud ${ }^{4,5, *}$ \\ 1 Inserm UMR1141 NeuroDiderot, Université de Paris, 75019 Paris, France; manuela.zinni@inserm.fr (M.Z.); \\ julien.pansiot@inserm.fr (J.P.); marina.el-kamouh@inrae.fr (M.E.K.) \\ 2 Pediatric and Neonatal Intensive Care Unit, Armand-Trousseau University Hospital, \\ Assistance Publique-Hôpitaux de Paris, Sorbonne University, 75019 Paris, France; pierre-louis.leger@aphp.fr \\ 3 Laboratoire de Physiologie et Génomique des Poissons-INRAE, 35700 Rennes, France \\ 4 Laboratory of Child Growth and Development, University of Geneva, 1211 Geneva, Switzerland \\ 5 Division of Neonatology and Pediatric Intensive Care, Children's University Hospital of Geneva, \\ 1211 Geneva, Switzerland \\ * Correspondence: olivier.baud@unige.ch; Tel.: +41-795-534-204
}

check for

updates

Citation: Zinni, M.; Pansiot, J.; Léger, P.-L.; El Kamouh, M.; Baud, O.

Sildenafil-Mediated Neuroprotection from Adult to Neonatal Brain Injury:

Evidence, Mechanisms, and Future

Translation. Cells 2021, 10, 2766.

https://doi.org/10.3390/

cells10102766

Academic Editors: Antonio

Rodríguez-Sinovas, Marisol

Ruiz-Meana and Javier Inserte

Received: 8 July 2021

Accepted: 7 October 2021

Published: 15 October 2021

Publisher's Note: MDPI stays neutral with regard to jurisdictional claims in published maps and institutional affiliations.

Copyright: (c) 2021 by the authors. Licensee MDPI, Basel, Switzerland. This article is an open access article distributed under the terms and conditions of the Creative Commons Attribution (CC BY) license (https:// creativecommons.org/licenses/by/ $4.0 /)$.

\begin{abstract}
Cerebral stroke, traumatic brain injury, and hypoxic ischemic encephalopathy are among the most frequently occurring brain injuries. A complex pathogenesis, characterized by a synergistic interaction between alterations of the cerebrovascular system, cell death, and inflammation, is at the basis of the brain damage that leads to behavioral and neurodevelopmental disabilities in affected subjects. Sildenafil is a selective inhibitor of the enzyme phosphodiesterase 5 (PDE5) that is able to cross the blood-brain barrier. Preclinical data suggest that sildenafil may be a good candidate for the prevention or repair of brain injury in both adults and neonates. The aim of this review is to summarize the evidence supporting the neuroprotective action of sildenafil and discuss the possible benefits of the association of sildenafil with current therapeutic strategies.
\end{abstract}

Keywords: sildenafil; neuroprotection; brain injury

\section{Introduction}

Cerebral stroke and traumatic brain injury (TBI) in adults and stroke and hypoxic ischemic encephalopathy (HIE) in neonates are among the most frequently occurring brain injuries recorded worldwide [1-3]. Despite the difference in developmental stage at the time of insult, these pathologies are all characterized by similarities in alterations of brain physiology and function. The brain damage and subsequent behavioral disorders and neurodevelopmental impairment are the result of a complex pathogenesis, defined by a synergistic interaction between alterations of the cerebrovascular system, cell death, and inflammation. Therapeutic strategies targeting cerebrovascular system, cell death, and the brain inflammatory response may represent a plausible therapeutic approach. Sildenafil is a selective inhibitor of the enzyme phosphodiesterase 5 (PDE5) and studies performed on animal models have demonstrated its ability to modulate these processes in the context of adult and neonatal brain injury and disease. The aim of this review is to summarize the evidence supporting the protective action of sildenafil in the developing and mature brain.

\section{Materials and Methods}

A literature search was performed in September 2021 using the Pubmed and Google Scholar databases in English without any restriction of the year, species, or authors. The following keywords were used in title (both Pubmed and Google Scholar search) or in abstract (Pubmed search): sildenafil or PDE5 inhibitor and stroke (121 articles), sildenafil or PDE5 inhibitor and traumatic brain injury (6 articles), sildenafil PDE5 inhibitor and hypoxic ischemic encephalopathy (1 article), sildenafil PDE5 inhibitor and neuroinflammation 
(24 articles), sildenafil PDE5 inhibitor and cerebral blood flow (28 articles), sildenafil PDE5 inhibitor and cell death (40 articles). An additional manual search was performed based on the references included in the selected research papers. Review papers were used as references only for general concepts. Only papers that met the following criteria were included: pertinence to the subject, presence of control groups, and clear descriptions of experimental procedures.

\section{Nitric Oxide Pathway and Sildenafil: Key Modulators of Cerebral Blood Flow (CBF)}

\subsection{Nitric Oxide and CBF}

The role of $\mathrm{CBF}$ in the pathogenesis of both adult and neonatal brain injury and disease has been clearly established. Restoration of the cerebral blood supply could thus represent a plausible therapeutic option for such brain injuries. In this context, the modulation of the nitric oxide (NO) pathway may represent a relevant target [4].

Preclinical pharmacological studies have shown a direct link between CBF and NO signaling. In vivo administration of L-NAME (NOS inhibitor) reduces cortical and hypothalamic CBF and increases the arterial blood pressure in rats, mice and lambs [5-8]. Coumans et al. and Hunter et al. demonstrated that L-NAME administration prevents the increase of $\mathrm{CBF}$ induced by exposure to hypoxia in preterm and term sheep [5,9]. Consistent with these observations, a study performed on endothelial NOS (eNOS) KO mice showed the reduction of CBF in response to TBI to be greater in mutant mice than in WT animals [10].

A strategy to increase $\mathrm{NO}$ levels and consequently restore and increase CBF is represented by the inhalation of NO. Inhaled nitric oxide (iNO), approved by the US Food and Drug Administration (FDA) for the treatment of persistent pulmonary hypertension in newborns [11], was initially studied in the context of brain stroke by Terpolilli et al. in 2012. The authors demonstrated, for the first time, the ability of iNO to reach the brain vasculature and directly induce cerebral venodilation when administrated at a dose of $50 \mathrm{ppm}$ to healthy mice. Starting from this initial observation, Terpolilli et al. used an elegant multispecies approach to show that $50 \mathrm{ppm}$ iNO induces venule and arteriole dilation and significantly increases perfusion of the penumbra in a mouse model of neonatal HIE and in mouse and sheep stroke models. The increased collateral CBF induced by NO inhalation was associated with a significant reduction in ischemic brain damage [12]. The protective effect of $\mathrm{NO}$ was confirmed by successive studies in preclinical models of neonatal ischemia in rats that showed a significant reduction of lesion size $72 \mathrm{~h}(50 \mathrm{ppm}$ iNO) and $48 \mathrm{~h}$ (20 ppm iNO) after the induction of stroke and an increase in blood flow velocity $[13,14]$.

Despite the beneficial effects observed in preclinical studies, the use of iNO in the context of brain injury presents several limitations, including dosage and the window of exposure.

\subsection{Phosphodiesterases (PDEs) and CBF: A Key Role for Sildenafil}

Another strategy to modulate NO pathway is to control cyclic guanosine- $3^{\prime}$, $5^{\prime}$-monophosphate (cGMP) concentration, that mediates most of the biological effects of NO [15]. The enzyme soluble guanylyl cyclase (sGC) is the major physiological NO receptor in the brain and its activation occurs via a conformational change upon the binding of NO to the prosthetic heme, after which it catalyzes the conversion of GTP to cGMP. The increase in the intracellular cGMP concentration directly mediates the effects of NO and induces the activation of downstream cGMP-dependent protein kinases and cGMP-gated ion channels [16-19].

The stability of cGMP is a critical regulator of NO signal transduction and is dependent on the activity of phosphodiesterases (PDEs), of which 11 mammalian isoforms have been described. PDEs can be classified into three groups depending on their specificity: (i) cyclic AMP-specific (PDE4, PDE7, and PDE8), (ii) cyclic GMP-specific (PDE5, PDE6, and PDE9), (iii) and those that hydrolyze both cyclic GMP and AMP (PDE1, PDE2, PDE3, PDE10, and PDE11). Almost all PDE isoforms are expressed in the brain $[20,21]$. Due to their key role 
in the modulation of NO signaling, the inhibition of PDE activity to prolong the half-life of cGMP could represent a second therapeutic strategy to enhance the effect of endogenous $\mathrm{NO}$ and its effect on CBF in the context of brain injury.

In particular, PDE5 is a GMP-specific PDE that is highly expressed in vascular smooth cell (VSMCs) and among the most abundant in arterial smooth cells (SMCs) [22]. Its expression has been reported in cerebral and meningeal arteries, both in humans and rodents [23].

Sildenafil, a highly potent selective inhibitor of PDE5, was originally developed for the treatment of hypertension and angina pectoris and is currently approved by the FDA for the treatment of erectile dysfunction and primary pulmonary hypertension $[24,25]$. Sildenafil is a blood-brain barrier permeable drug [26] and the interest in its use for the treatment of brain diseases characterized by alterations of CBF originated from preclinical studies performed in mice and rabbits that showed a protective role of sildenafil against ischemia-reperfusion injury in the heart [27-29] (Figure 1).

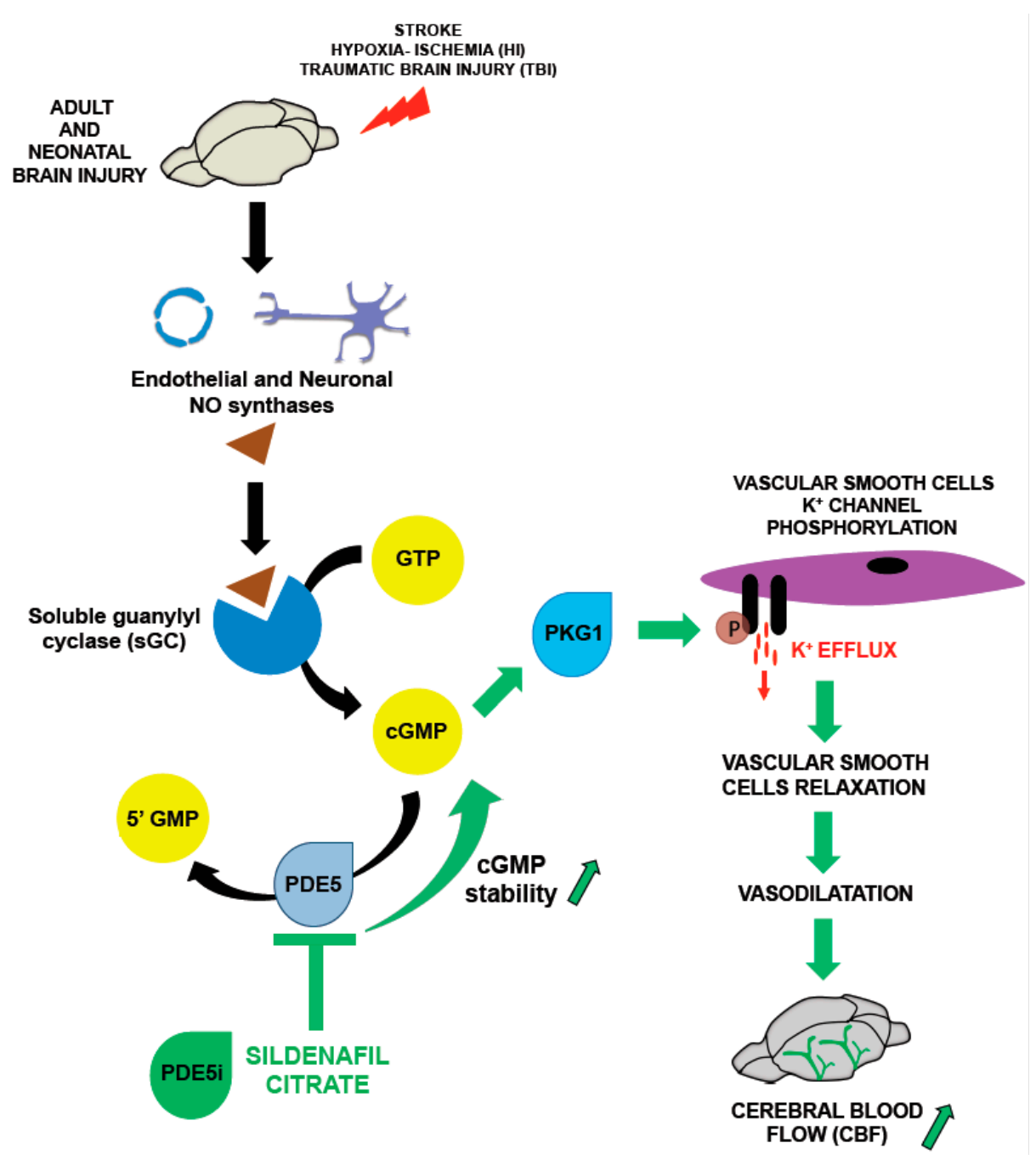

Figure 1. Sildenafil and the modulation of cerebral blood flow (CBF): the binding of NO to sGC, the main NO physiological receptor, stimulated the synthesis of cGMP, which binds to and activates cGMP-dependent protein kinase I (PKG1). Activated PKG1 then phosphorylates the alpha subunit of the vascular smooth cell $\mathrm{K}^{+}$channel, resulting in a $\mathrm{K}^{+}$efflux, cell hyperpolarization, vascular smooth cell relaxation and in an increase of CBF. Sildenafil modulate cGMP stability via inhibition of the enzyme PDE5 that catalyzes the conversion of cGMP into the 5' GMP inactive form. 
In adult rats, a single injection of sildenafil $(10 \mathrm{mg} / \mathrm{kg})$ was reported to induce an $8 \%$ increase in CBF six weeks after permanent middle cerebral arterial occlusion (MCAO) [30]. Increased CBF in adult rats six weeks after MCAO was also reported after chronic treatment with sildenafil $(10 \mathrm{mg} / \mathrm{kg} / \mathrm{d}$ for 7 days) in two other studies [31,32].

In the developing rodent brain, we previously demonstrated that a single intraperitoneal injection of sildenafil at a dose of $10 \mathrm{mg} / \mathrm{kg}$ promoted CBF in a rat model of neonatal hypoxia-ischemia by increasing arterial blood flow velocity (BFV) in the basilar trunk (BT) and the contralateral internal carotid (ICA) one hour after drug injection [33].

\section{Other Effects of Sildenafil in the Brain}

The pathogenesis of brain injury is usually characterized by activation of an abnormal inflammatory response, apoptotic and necrotic processes, and the release/accumulation of reactive oxygen species and other excitotoxic molecules.

We summarize here evidence supporting the ability of sildenafil to target and modulate pathological processes other than CBF (Figure 2). In addition to modulation of CBF, the main effects of sildenafil in animal models of brain injury in adults and neonatal rodents are summarized in the Table 1.

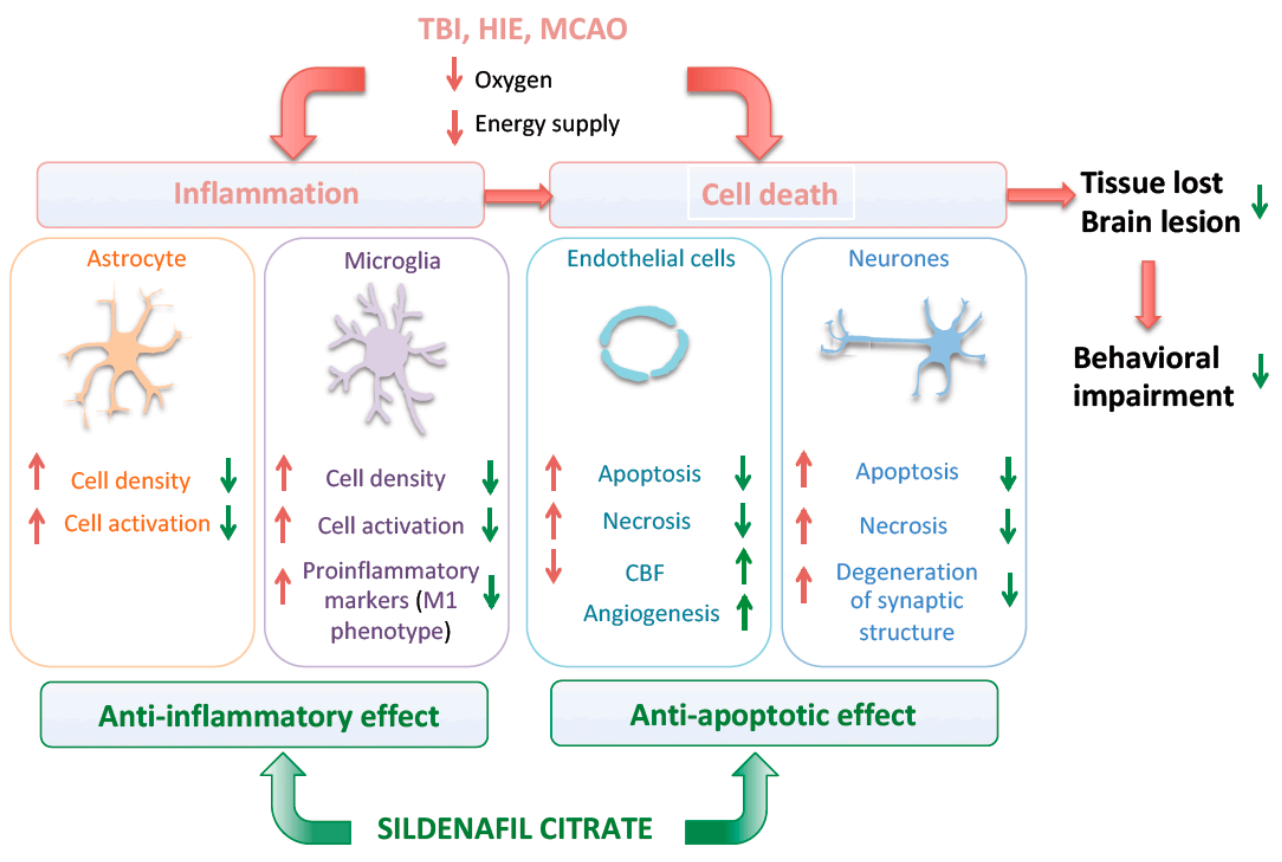

Figure 2. Cellular mechanism associated with the neuroprotective effect of sildenafil.

Table 1. Main effects of sildenafil according to preclinical models of brain injury from neonatal to adult rodents. HI: hypoxia-ischemia; TBI/Cryo: traumatic brain injury/cryolesion.

\begin{tabular}{ccccc}
\hline \multirow{2}{*}{ Effect } & Neonatal & Juvenile & \multicolumn{2}{c}{ Adult } \\
\cline { 2 - 5 } & & HI & + & TBI/Cryo \\
\hline CBF & +++ & + & + & $?$ \\
\hline Angiogenesis & $+/-?$ & + & & + \\
\hline Inflammation & +++ & & ++ & + \\
\hline Cell death & ++ & ++ & ++ & $?$ \\
\hline Neurogenesis & + & ++ & & \\
\hline
\end{tabular}




\subsection{Angiogenesis}

Aside from its effects on vascular reactivity, sildenafil has also been shown to be a key modulator of angiogenesis.

Endogenous NO and NO donors promote endothelial cell (EC) migration and growth and the formation of tube-like structures in vitro, as well as angiogenesis in vivo [34-38]. A pro-angiogenic effect of sildenafil was recently demonstrated combining in vivo and in vitro studies in chicken chorioallantoic membranes (CAMs) and endothelial cells. In particular, Pyriochou et al. showed that $48 \mathrm{~h}$ of treatment with sildenafil significantly increased the length of vessels in CAMs and stimulated EC migration and their organization into vessel-like structures [39].

Histological analysis of MCAO rodent models for both aged and juvenile rats showed sildenafil treatment to increase the number of blood vessels and proliferating endothelial cells in the peri-ischemic region one week after surgery [40,41]. Several studies confirmed the increase of angiogenesis by MRI $[30,32]$ and a similar angiogenic effect was observed in cryolesioned mice three days after injury [42].

In a neonatal rat HIE model, sildenafil treatment $(10 \mathrm{mg} / \mathrm{kg})$ reduced microvessel damage, as shown by a significant reduction in the number of TUNEL-positive endothelial cells at day 3 post HI. Furthermore, the authors showed protection of the integrity of the blood-brain barrier, shown by a reduction in IgG extravasation in treated animals [33]. The effect of sildenafil administration on angiogenesis in a P10 neonatal rat HIE model is a subject of debate $[33,43]$. Indeed, oral administration of sildenafil for seven days at a dose comparable to that used by Charriaut-Marlangue et al. had no effect on microvessel density, whereas a significant decrease was reported in response to treatment with $50 \mathrm{mg} / \mathrm{kg}$ 20 days after injury [43]. This discrepancy concerning the long-term use of sildenafil with the results of previous adult and neonatal studies was suggested by Yazdani et al. [43] to be the consequence of the physiologically regenerative angiogenesis observed in response to HI, even in the absence of treatment [44-46], which hide the earlier angiogenic effect of sildenafil.

\subsection{Neuro-Inflammation}

The brain inflammatory response is regulated by a crosstalk between microglia and astrocytes [47]. A change in microglia and astrocyte reactivity has been reported to be an important component in the pathogenesis of brain injury disease $[48,49]$.

Cold-light photothrombotic occlusion in the cortical vasculature was found to be associated with an increase in the density of microglia in the ipsilateral hemisphere in adult mice and rats from day 8 to day 28 post stroke [50,51]. Strong immunoreactivity for the specific astrocytic marker glial fibrillary acidic protein (GFAP) was observed by Patience et al. on the ipsilateral side of the brains of adult mice in comparison to the sham animals in the same model [52]. Two other studies performed using the adult MCAO mouse model reported the presence of activated amoeboid microglia and active microglial proliferation in the peri-infarct area [53,54]. Similarly, a significant and prolonged increase in GFAP protein and mRNA levels was reported in a cortical stroke model in response to mild and severe ischemia in rats [55]. In accordance with these observations, increased expression of pro-inflammatory markers (e.g., tumor necrosis factor alpha (TNF $\alpha$ ) and Interleukin-1 $\beta$ (IL-1 $\beta)$ ) has been described in both animals and humans after an ischemic stroke [56-59].

Consistent with the anti-inflammatory action of sildenafil in HI, a single subcutaneous injection of sildenafil $(10 \mathrm{mg} / \mathrm{kg})$ in adult mice, before and 24 and $48 \mathrm{~h}$ after the induction of a cortical cryolesion significantly reduced the density of activated microglia and increased astrocyte reactivity three days after injury [42]. In another study, chronic sildenafil treatment $(2 \mathrm{mg} / \mathrm{kg} /$ day $)$ reduced the expression of the inflammatory markers monocyte chemoattractant protein-1 (MCOP-1) and IL-1 $\beta$ in P28 rats subjected to multiple microinfarction [60]. 
In neonatal pups, an increase in microglia cell density and activation in the penumbra, in addition to a strong astrocytic response, was described, both in a permanent MCAO mouse model and a rat model of HIE, three days and one week after injury [33,61]. In these models, a single intraperitoneal administration of sildenafil (10 mg/ kg) was found to reduce the density and activation of microglia in the penumbra three and seven days following MCAO [33,61]. Furthermore, Moretti et al. showed that sildenafil induces a shift in microglia polarization toward an M2 anti-inflammatory phenotype seven days after brain injury [61]. Interestingly, the upregulation of astrocyte reactivity in the areas of the peri-lesion site three days after the induction of stroke was found to be associated with changes in $\mathrm{CBF}$ in response to $\mathrm{MCAO}$ [61].

\subsection{Cell Death}

Neuronal cell death is the result of multiple mechanisms (e.g., excitotoxic cell death, necrosis, and apoptosis) activated by the reduction of oxygen and energy supply [62]. Neuronal loss has been unanimously reported in animal models of brain injury related to stroke, hypoxia and TBI and the magnitude of tissue loss has been reported to be an important variable in functional recovery $[43,62,63]$.

Pre-clinical studies performed in rodents have highlighted the ability of sildenafil to reduce lesion size in both the adult and developing brain. Moretti and Charriaut-Marlangue demonstrated that a single intraperitoneal administration of sildenafil $(10 \mathrm{mg} / \mathrm{kg})$ after surgery can significantly reduce the percentage of tissue loss one week after the injury in two independent studies on mouse and rat models of neonatal stroke and HI $[33,61]$. Similarly, the oral administration of sildenafil $(10 \mathrm{mg} / \mathrm{kg} / \mathrm{d})$ for one week to neonatal rats was reported to significantly increase the volume of the ipsilateral hemisphere three weeks after HI [43]. Studies performed in adult models further confirmed the results observed in pups. Sildenafil administration was indeed reported to reduce the number of degenerating neurons and increase the number of surviving cortical and striatum neurons in MCAO rats. Interestingly this pro-survival effect was associated with reduced degeneration of the synaptic structure and an improvement in behavioral performance [63]. The reduction of cell death induced by sildenafil has been described both in mice with cortical cryolesions (reduction in TUNEL-positive cell density) and those with chemically-induced cerebral ischemia (increased expression of the anti-apoptotic proteins Bcl-2 and Bcl-xl) $[42,64]$.

The effect of sildenafil on cell death in the context of TBI has been investigated little. However, a recent study performed in a rat TBI model confirmed the neuroprotective effect of sildenafil, with a decrease in neuronal cell death, as shown by a reduction in the density of neurons with pyknotic nuclei in the prefrontal cortex and hippocampus [65].

\subsection{Neurogenesis}

An increase in neurogenesis in the subventricular zone to promote the migration of newborn neurons into the ischemic boundary area is among the mechanisms involved in the normal repair process widely described in adult rat models of ischemic stroke [66-69]. Emerging evidence suggests that sildenafil could contribute to neuroprotection by increasing neurogenesis. Sildenafil has been shown to increase the number of immature and mature neurons in the ischemic brain when administrated for seven consecutive days to juvenile and adult animals following middle cerebral artery occlusion [70,71]. In addition, an increase in the neuronal density within the boundary of the ischemic core has been observed following sildenafil treatment three weeks after neonatal $\mathrm{HI}$ in rats [43].

\section{Sildenafil Exposure and Behavioral Outcomes in Response to Brain Injury}

Neurological sequelae are a common pathological outcome of stroke and hypoxic ischemic encephalopathy (HIE) in the neonate and of stroke and TBI in adult. Cognitive disabilities including memory deficit and language deficits are indeed reported in the $60 \%$ of children with perinatal stroke and are identified in the $30 \%$ of adult stroke patients 
within the first year after the brain injury event [72,73]. Similarly cognitive and behavioral alterations are reported in the $30 \%$ of patients surviving to TBI [74].

Birth complications are considered as an important risk factor for insurgence of the cerebral palsy (CP), a severe condition of motor disabilities observed in children [75]. In agreement with this observation, clinical data identified perinatal stroke as a causal factor in the $50 \%$ of the infants born at term and affected by a hemiplegic CP $[76,77]$.

Pre-clinical studies performed on neonatal and adult animal models evidenced the ability of sildenafil treatment to modulate and reverse the brain injury-induced behavioral alterations. A single intraperitoneal administration of sildenafil $(10 \mathrm{mg} / \mathrm{kg})$ after surgery is able to mitigate the altered exploratory behavior and general activity observed in response to a neonatal HI event in mice, seven days after surgery [33].

Studies performed in adult model confirmed the results obtained in pups. Seven days administration of sildenafil (intravenous $16 \mathrm{mg} / \mathrm{kg}$ ) significantly improved the motor coordination performance in a rat adult model of MCAO [63]. Similarly, Zhang et al. demonstrated in two independent studies the beneficial effect of a chronic sildenafil treatment on the neurological score and the motor performance $[40,70]$.

\section{Sex Difference in Brain Injury Outcome}

Sex is widely recognized as a factor influencing the clinical outcome in response to HI, stroke and TBI in both neonatal and adult ages.

Neonatal brain injury is clinically associated to a worse outcome in male infants and a higher mortality rate has been reported in male in comparison to female [78-81]. Similarly, disorientation and loss of consciousness following TBI in human adults were found to be more frequent in men in comparison to women [82,83].

Pre-clinical studies designed to investigate the underlining mechanism of this sexdependent vulnerability of the brain reported conflicting results. The severity of the neurological outcome has been described to be dependent on the developmental stage at the time of injury. $\mathrm{HI}$ induced in $\mathrm{P} 3$ rats was associated to a greater cognitive impairment and to a greater white matter histological damage in females than in males [84]. In contrast, a higher mortality rate, a higher cognitive impairment and a greater injury severity was reported in P10 male rats [85]. Similarly, an greater vulnerability was observed in male mice exposed to hypoxia from P3 to P11 with an increased hippocampal tissue loss and white matter damage in comparison to female [86].

Studies performed on an animal model of TBI highlighted a complex interaction between sex and injury outcomes. $\mathrm{O}^{\prime}$ Connor et al. evidenced a better behavioral performance in cognitive task in female compared to male [87] whereas, in two other studies, a greater mortality rate was observed in female rats [88] or no change in brain damage was reported between female and male after TBI [89].

The role of sexual hormones progesterone and estrogen as neuroprotectants is supported by preclinical studies showing that ovariectomy exacerbated brain injury [90,91]. However, sex difference in the outcome of brain injury appears to be very complex and is not only limited to the different level of sexual hormones between male and female. As recently reviewed by Charriaut-Marlangue et al. [92] and by Murden et al. [81], differences in cell death pathways, exacerbated microglia activation, and abnormal response to oxidative stress in males are suggested to play a key role.

The effect of sex on sildenafil mediated neuroprotection remains unknown and only one study performed in $\mathrm{P9}$ pups mice evidenced that inhaled nitric oxide reduces brain injury three days after HI, only in males [13].

\section{Other PDE5 Inhibitors as Potential Neuroprotectors in Preclinical Models}

In addition to the neuroprotective role of sildenafil reviewed above, other selective PDE5is have been tested in preclinical models of brain injury [93].

Tadalafil is a long-lasting PDE5i with a rapid onset of action and several studies have shown its ability to modulate inflammation, neurogenesis, and cell death in response to 
prenatal hypoxic brain injury and to cerebral ischemia and stroke in adults [94-99]. A recent study performed by Tachibana et al. showed that three days (from E14 to E17) in utero administration of tadalafil is neuroprotective in a mouse model of induced preeclampsia with fetal growth restriction (FGR). In particular, the authors demonstrated that the increased astrocyte cell density observed in the corpus callosum of FGR mice was significantly reduced and synaptogenesis and myelination significantly increased in tadalafil-treated animals at P15 and P30 [94]. The protective effect observed in neonatal models was further confirmed by other studies performed in adult rodent models of cerebral HI. Zhang et al. showed oral administration of tadalafil ( 2 and $10 \mathrm{mg} / \mathrm{kg}$ administrated every $48 \mathrm{~h}$, starting $24 \mathrm{~h}$ after the insult) to significantly increase angiogenesis and endothelial cell proliferation in the peri-infarct area and improve neurological recovery in embolic stroked animals [97]. An improvement of cognitive and motor ability associated with a reduction in the size of the brain lesion was also observed in response to pretreatment with tadalafil in a mouse model of ischemia and reperfusion injury [96,98]. Moreover, seven days of oral administration of tadalafil was associated with significantly reduced CA1 hippocampal neuronal cell death and improved short-term memory in an adult gerbil model of transient global ischemia [99].

Finally, a limited number of studies is available on the neuroprotective effect of two others PDE5is: zaprinast and yonkenafil [100,101]. In particular, zaprinast, known for its specific PDE5i activity, has also been shown to be a modulator of peroxisome proliferator-activated receptor gamma (PPAR $\gamma$ ) and an agonist of G-protein coupled receptor 35 (GPR35), which is involved in the modulation of inflammatory pain [102-104]. The two drugs were investigated by Gao et al. and Chen et al. in a rat model of MCAO occlusion. Zaprinast treatment significantly increased CBF and reduced the size of brain lesions when administrated intravenously at a dose of $10 \mathrm{mg} / \mathrm{kg} 10 \mathrm{~min}$ after permanent MCAO [100]. The study performed by Chen et al. in a model of ischemia and reperfusion injury showed that yonkenafil treatment significantly reduced lesion size and neuronal cell death in the cortex and striatum. The reduced neuronal loss was associated with an improvement of neurological outcome and a reduction in the loss of synapses in both the cortex and striatum [101].

\section{Main Human Brain Injuries in Adults and Neonates as Potential Targets for Sildenafil}

\subsection{Adult Brain Injury}

Ischemic stroke and TBI are two major causes of disability and mortality in adults. Their worldwide incidence has been steadily increasing and their annual incidence in Europe is 7-8/100,000 [105] and 10-12/100,000 [106], respectively.

Vascular risk factors, such as hypertension, hypercholesterolemia, diabetes, obesity, and smoking, have been identified as a major cause in the increasing incidence of stroke [107]. Depending on the severity of the injury and the duration of CBF reduction and subsequent oxygen and glucose deprivation, ischemic stroke can be classified as focal or global and transient or permanent [108]. Three different areas are defined on the basis of the morphological, biochemical, and structural alterations observed: (i) core, (ii) penumbra, and (iii) benign oligemia. The core region corresponds to the core of the stroke and represents the tissue that is irreversibly compromised, whereas the penumbra and benign oligemia identify the tissue surrounding the core area that is still viable and potentially recoverable, either spontaneously or by therapeutic treatment, including sildenafil [109].

TBI is generally the consequence of an external mechanical insult and its pathophysiology is defined by primary and secondary brain injury [110]. Primary injury is linked to the mechanical insult and is clinically identified by the presence of skull fracture, coup and contrecoup contusions and cerebral hemorrhage. The outcome of the functional and structural alterations observed in the primary injury promote the appearance of secondary injury, defined by the development of edema, compression of the cerebral tissues, an increase in intracranial pressure, a decrease in $\mathrm{CBF}$, and the appearance of ischemic brain damage, the latter identified in more than $90 \%$ of TBI patients [110-113]. Alterations in 
CBF induced by TBI are characterized by an initial large decrease, followed by an increase, and studies confirmed the association between $\mathrm{CBF}$ and poor outcomes for patients with severe TBI [114-116].

\subsection{Neonatal Brain Injury}

In term-neonates, stroke and hypoxic ischemic encephalopathy (HIE) related to perinatal asphyxia are two major causes of perinatal death and long-term neurological disabilities, including cerebral palsy, mental retardation, and epilepsy $[117,118]$.

Neonatal stroke is clinically defined as cerebrovascular events that occur between week 20 of gestation and the first 28 postnatal days [119]. Epidemiological data have shown an annual incidence of $1 / 2500$ to $1 / 5000$ and an annual mortality rate estimated to be $3.5 / 100,000$ [119-122]. Although perinatal stroke affects both preterm and term neonates, the brain injury profile reflects the maturational stage of the brain at the time of the stroke. Exposure to stroke in preterm babies occurs during a critical period for the differentiation of oligodendrocyte progenitors (OPC) to mature myelinating neural cells, a process disrupted by microglial activation and neuro-inflammation. Due to such a temporal overlap, neonatal stroke in infants born preterm has been shown to be a strong predisposing factor for periventricular white-matter injury and cerebral palsy [123-125]. Conversely, a lesion observed in the gray matter, mainly in the cortex, thalamus, and striatum, has been reported for term infants in response to stroke [120].

In addition, poor perfusion of the placenta, preeclampsia, and chorioamnionitis are clinically associated with a reduction in fetal CBF and a risk of neonatal stroke [126-128].

HIE is a major complication commonly observed in term neonates following perinatal asphyxia leading to high incidence of neonatal death and long-term neurodevelopmental impairment [117]. Its incidence has been recently estimated to be 1.5 per 1000 live births in developed countries and between 2.3 and 26.5 per 1000 live births in developing countries $[117,129]$. The exact event linked to HIE in term neonates is sometimes unknown. However, the clinical history of infants affected by HIE showed cord prolapse, uterine rupture, placenta praevia, and maternal hypotension to be important causal factors [117].

Reduced CBF and the subsequent reduction in the supply of oxygen to the brain are the two key elements in the pathophysiology of HIE and stroke in neonates responsible for the activation of a cascade of processes and cellular mechanisms, identified as primary and secondary energy failure $[117,130,131]$. Primary energy failure in cerebral stroke and HIE is the direct consequence of reduced $\mathrm{CBF}$ and oxygen and glucose deprivation, leading to a major challenge to cell integrity. Normal cellular physiology and the biological processes involved in the maintenance of cell homeostasis are disrupted, with the consequent release of glutamate, increase in intracellular calcium and sodium, and activation of necrotic and apoptotic processes. Secondary energy failure, well documented following HIE, occurs between 6 and $48 \mathrm{~h}$ after the initial injury and is associated with the detrimental consequences of an abnormal inflammatory response, the accumulation of reactive oxygen species and the release of excitotoxic molecules [117]. Many of these biological responses to perinatal asphyxia are potential targets of sildenafil.

\section{Future Perspectives}

Based on preclinical observations (Table 1), sildenafil has been tested in human clinical trials to evaluate its efficacy in the treatment of adult brain diseases and injury characterized by alterations in cerebral hemodynamic function (Table 2).

Some trials have not yet been completed and some of them have been interrupted due to slow recruitment. However, a recent study performed on patients with chronic TBI demonstrated an improvement in vascular functionality in response to drug treatment [132]. A single oral administration of sildenafil (50 $\mathrm{mg}$ ) was associated with an increase in and normalization of cerebrovascular reactivity in adult TBI subjects [132]. 
Table 2. Ongoing or completed clinical trials testing sildenafil to prevent brain injury.

\begin{tabular}{|c|c|c|c|c|c|c|}
\hline NCT/Status/Study Title & Condition & Comparator & Phase & Primary Outcome & Main Effect & Comment/Reference \\
\hline $\begin{array}{c}\text { NCT02628847 (Terminated) } \\
\text { Sildenafil and Stroke Recovery }\end{array}$ & Adult stroke & Placebo & 1 & $\begin{array}{l}\text { Motor recovery at } \\
\text { one and three } \\
\text { months }\end{array}$ & Unknown & $\begin{array}{l}\text { Recruitment was } \\
\text { problematic }\end{array}$ \\
\hline $\begin{array}{l}\text { NCT00452582 (Terminated) } \\
\text { Sildenafil (Viagra) Treatment of } \\
\text { Subacute Ischemic Stroke }\end{array}$ & $\begin{array}{l}\text { Adult ischemic } \\
\text { stroke }\end{array}$ & Usual care & 1 & $\begin{array}{l}\text { The maximum } \\
\text { tolerated dose and } \\
\text { toxicity profile of } \\
\text { sildenafil treatment } \\
\text { in patients with } \\
\text { subacute ischemic } \\
\text { stroke }\end{array}$ & $\begin{array}{l}\text { Sildenafil appeared } \\
\text { to be safe in patients } \\
\text { with mild to } \\
\text { moderately severe } \\
\text { stroke }\end{array}$ & $\begin{array}{l}\text { Failure to recruit in } \\
\text { expected time } \\
\text { period }\end{array}$ \\
\hline $\begin{array}{c}\text { NCT03855332 (Recruiting) } \\
\text { Oxford Haemodynamic } \\
\text { Adaptation to Reduce Pulsatility } \\
\text { Trial (OxHARP) }\end{array}$ & $\begin{array}{l}\text { Small vessel } \\
\text { cerebrovascu- } \\
\text { lar disease in } \\
\text { adult }\end{array}$ & $\begin{array}{l}\text { Cilostazol } \\
\text { Placebo }\end{array}$ & 2 & $\begin{array}{l}\text { Middle cerebral } \\
\text { arterial pulsatility } \\
\text { index }\end{array}$ & - & $\begin{array}{l}\text { Estimated study } \\
\text { completion date: } \\
\text { December } 2022\end{array}$ \\
\hline $\begin{array}{c}\text { NCT01762475 (Completed) } \\
\text { Sildenafil for Cerebro-vascular } \\
\text { Dysfunction in Chronic Traumatic } \\
\text { Brain Injury }\end{array}$ & $\begin{array}{l}\text { Traumatic } \\
\text { brain injury in } \\
\text { adults }\end{array}$ & - & 2 & $\begin{array}{l}\text { Cerebrovascular } \\
\text { reactivity }\end{array}$ & $\begin{array}{l}\text { Single-dose } \\
\text { sildenafil improves } \\
\text { regional CVR } \\
\text { deficits in chronic } \\
\text { TBI patients } \\
\end{array}$ & [116] \\
\hline $\begin{array}{c}\text { NCT02114775 (Completed) } \\
\text { Growth Hormone or Sildenafil as } \\
\text { Therapies for Fatigue in } \\
\text { Mild-Traumatic-brain-injury } \\
\text { (MTBI) }\end{array}$ & $\begin{array}{l}\text { Traumatic } \\
\text { brain injury in } \\
\text { adults }\end{array}$ & $\begin{array}{l}\text { Genotropin } \\
\text { Placebo }\end{array}$ & 1 & Performance fatigue & Unknown & $\begin{array}{l}\text { Sildenafil was } \\
\text { found to increase } \\
\text { protein synthesis } \\
\text { and reduces muscle } \\
\text { fatigue in healthy } \\
\text { men }\end{array}$ \\
\hline $\begin{array}{c}\text { NCT04058132 (Recruiting) } \\
\text { Cerebrovascular Reactivity } \\
\text { Assessed With fNIRS as a } \\
\text { Biomarker of TCVI After Acute } \\
\text { Traumatic Brain Injury in Military }\end{array}$ & $\begin{array}{l}\text { Acute/subacute } \\
\text { traumatic brain } \\
\text { injury in adults }\end{array}$ & None & 2 & $\begin{array}{l}\text { Variation of } \\
\text { oxyhemoglobin and } \\
\text { deoxyhemoglobin } \\
\text { concentration } \\
\text { Longitudinal } \\
\text { measure of CVR }\end{array}$ & - & $\begin{array}{l}\text { Estimated study } \\
\text { completion date: } \\
\text { April } 2021\end{array}$ \\
\hline $\begin{array}{c}\text { NCT02990078 (Recruiting) } \\
\text { Non-invasive Measurement of } \\
\text { Cerebrovascular Reactivity After } \\
\text { Traumatic Brain Injury }\end{array}$ & $\begin{array}{l}\text { Traumatic } \\
\text { brain injury in } \\
\text { adults }\end{array}$ & None & 1 & Change in CVR & - & $\begin{array}{l}\text { Estimated study } \\
\text { completion date: } \\
\text { December } 2026\end{array}$ \\
\hline $\begin{array}{l}\text { NCT03417492 (Recruiting) } \\
\text { Cerebrovascular Reactivity in } \\
\text { American Football Players }\end{array}$ & $\begin{array}{l}\text { Traumatic } \\
\text { brain injury in } \\
\text { adults }\end{array}$ & None & 1 & $\begin{array}{l}\text { Effect of single dose } \\
\text { sildenafil citrate on } \\
\text { global BOLD } \\
\text { response to } \\
\text { hypercapnia }\end{array}$ & - & $\begin{array}{l}\text { Estimated study } \\
\text { completion date: } \\
\text { September } 2022\end{array}$ \\
\hline $\begin{array}{c}\text { NCT02812433 (Active) } \\
\text { Sildenafil Administration to Treat } \\
\text { Neonatal Encephalopathy }\end{array}$ & $\begin{array}{l}\text { Hypoxic } \\
\text { ischemic en- } \\
\text { cephalopathy } \\
\text { in neonates }\end{array}$ & Ora-Blend & 1 & $\begin{array}{l}\text { Serious adverse } \\
\text { events }\end{array}$ & - & $\begin{array}{c}\text { Estimated study } \\
\text { completion date: } \\
\text { June } 2022\end{array}$ \\
\hline
\end{tabular}

The studies discussed in this review strongly suggest a neuroprotective role for sildenafil. Originally conceived as a PDE5 inhibitor for the treatment of cardiac and pulmonary dysfunction, sildenafil can modulate the complex and multiple pathogenic processes underlying the damage induced by stroke, HIE, and TBI brain injury.

In this context, the association of sildenafil with other therapeutic strategies could represent a good option to improve recovery after brain injury in both adults and neonates. A clinical trial is currently ongoing to evaluate the potential effect of the association of oral sildenafil and hypothermia, the only currently available therapy to treat term asphyxiated newborns (Sildenafil Administration to Treat Neonatal Encephalopathy (SANE) and Repair Brain Injury Secondary to Birth Asphyxia: A Randomized, Double-blind, Placebocontrolled Pilot Phase Ib Study; NCT02812433 and NCT04169191). Another multicenter randomized clinical trial is planned to start in 2022 to test the added value of parenteral sildenafil combined with hypothermia to prevent brain lesions following birth asphyxia (Shine trial).

Author Contributions: M.Z. and J.P. performed the literature review. M.Z., J.P., P.-L.L., M.E.K. and O.B. collectively analyzed the articles selected in this review paper. M.Z., J.P. and O.B. wrote the manuscript. All authors have read and agreed to the published version of the manuscript. 
Funding: This study was supported by grants from Inserm, the Universite Paris-Diderot, the Fondation Paralysie Cérébrale and by The Human Safety for Newborns, Generali Foundation.

Institutional Review Board Statement: Not Applicable.

Informed Consent Statement: Not Applicable.

Data Availability Statement: Not Applicable.

Conflicts of Interest: The authors declare no conflict of interest.

\section{References}

1. James, S.L.; Theadom, A.; Ellenbogen, R.G.; Bannick, M.S.; Montjoy-Venning, W.; Lucchesi, L.R.; Abbasi, N.; Abdulkader, R.; Abraha, H.N.; Adsuar, J.C.; et al. Global, regional, and national burden of traumatic brain injury and spinal cord injury, 1990-2016: A systematic analysis for the Global Burden of Disease Study 2016. Lancet Neurol. 2019, 18, 56-87. [CrossRef]

2. Clive, B.; Vincer, M.; Ahmad, T.; Khan, N.; Afifi, J.; El-Naggar, W. Epidemiology of neonatal stroke: A population-based study. Paediatr. Child Health 2019, 25, 20-25. [CrossRef] [PubMed]

3. Wafa, H.A.; Wolfe, C.D.; Emmett, E.; Roth, G.A.; Johnson, C.O.; Wang, Y. Burden of Stroke in Europe. Stroke 2020, 51, $2418-2427$. [CrossRef]

4. Toda, N.; Ayajiki, K.; Okamura, T. Cerebral Blood Flow Regulation by Nitric Oxide: Recent Advances. Pharmacol. Rev. 2009, 61, 62-97. [CrossRef] [PubMed]

5. Hunter, C.J.; Blood, A.B.; White, C.R.; Pearce, W.J.; Power, G.G. Role of Nitric Oxide in Hypoxic Cerebral Vasodilatation in the Ovine Fetus. J. Physiol. 2003, 549, 625-633. [CrossRef] [PubMed]

6. Hortobágyi, L.; Kis, B.; Hrabák, A.; Horvath, B.; Huszty, G.; Schweer, H.; Benyó, B.; Sándor, P.; Busija, D.W.; Benyó, Z. Adaptation of the hypothalamic blood flow to chronic nitric oxide deficiency is independent of vasodilator prostanoids. Brain Res. 2007, 1131, 129-137. [CrossRef] [PubMed]

7. Zoccoli, G.; Grant, D.A.; Wild, J.; Walker, A.M. Nitric oxide inhibition abolishes sleep-wake differences in cerebral circulation. Am. J. Physiol. Heart Circ. Physiol. 2001, 280, H2598-H2606. [CrossRef]

8. Dayoub, H.; Rodionov, R.N.; Lynch, C.; Cooke, J.P.; Arning, E.; Bottiglieri, T.; Lentz, S.R.; Faraci, F.M. Overexpression of Dimethylarginine Dimethylaminohydrolase Inhibits Asymmetric Dimethylarginine-Induced Endothelial Dysfunction in the Cerebral Circulation. Stroke 2008, 39, 180-184. [CrossRef]

9. Coumans, A.; Garnier, Y.; Supçun, S.; Jensen, A.; Hasaart, T.H.; Berger, R. The role of nitric oxide on fetal cardiovascular control during normoxia and acute hypoxia in 0.75 gestation sheep. J. Soc. Gynecol. Investig. 2003, 10, 275-282. [CrossRef]

10. Hlatky, R.; Lui, H.; Cherian, L.; Goodman, J.C.; O’Brien, W.E.; Contant, C.F.; Robertson, C.S. The Role of Endothelial Nitric Oxide Synthase in the Cerebral Hemodynamics after Controlled Cortical Impact Injury in Mice. J. Neurotrauma 2003, 20, 995-1006. [CrossRef]

11. Barnes, M.; Brisbois, E.J. Clinical use of inhaled nitric oxide: Local and systemic applications. Free. Radic. Biol. Med. 2020, 152, 422-431. [CrossRef]

12. Terpolilli, N.A.; Kim, S.-W.; Thal, S.C.; Kataoka, H.; Zeisig, V.; Nitzsche, B.; Klaesner, B.; Zhu, C.; Schwarzmaier, S.; Meissner, L.; et al. Inhalation of Nitric Oxide Prevents Ischemic Brain Damage in Experimental Stroke by Selective Dilatation of Collateral Arterioles. Circ. Res. 2012, 110, 727-738. [CrossRef]

13. Zhu, C.; Sun, Y.; Gao, J.; Wang, X.; Plesnila, N.; Blomgren, K. Inhaled Nitric Oxide Protects Males But not Females from Neonatal Mouse Hypoxia-Ischemia Brain Injury. Transl. Stroke Res. 2012, 4, 201-207. [CrossRef] [PubMed]

14. Charriaut-Marlangue, C.; Bonnin, P.; Gharib, A.; Leger, P.-L.; Villapol, S.; Pocard, M.; Gressens, P.; Renolleau, S.; Baud, O. Inhaled Nitric Oxide Reduces Brain Damage by Collateral Recruitment in a Neonatal Stroke Model. Stroke 2012, 43, 3078-3084. [CrossRef] [PubMed]

15. Lundberg, J.O.; Weitzberg, E.; Gladwin, M.T. The nitrate-nitrite-nitric oxide pathway in physiology and therapeutics. Nat. Rev. Drug Discov. 2008, 7, 156-167. [CrossRef] [PubMed]

16. Garthwaite, J. Glutamate, nitric oxide and cell-cell signalling in the nervous system. Trends Neurosci. 1991, 14, 60-67. [CrossRef]

17. Hollas, M.A.; Ben Aissa, M.; Lee, S.H.; Gordon-Blake, J.M.; Thatcher, G.R.J. Pharmacological manipulation of cGMP and NO/cGMP in CNS drug discovery. Nitric Oxide 2019, 82, 59-74. [CrossRef]

18. Ghalayini, I.F. Nitric oxide-cyclic GMP pathway with some emphasis on cavernosal contractility. Int. J. Impot. Res. 2004, 16, 459-469. [CrossRef]

19. Greene, S.J.; Gheorghiade, M.; Borlaug, B.A.; Pieske, B.; Vaduganathan, M.; Burnett, J.C.; Roessig, L.; Stasch, J.; Solomon, S.D.; Paulus, W.J.; et al. The cGMP Signaling Pathway as a Therapeutic Target in Heart Failure with Preserved Ejection Fraction. J. Am. Heart Assoc. 2013, 2, e000536. [CrossRef]

20. Menniti, F.; Faraci, W.S.; Schmidt, C.J. Phosphodiesterases in the CNS: Targets for drug development. Nat. Rev. Drug Discov. 2006, 5, 660-670. [CrossRef]

21. Picón-Pagès, P.; Garcia-Buendia, J.; Muñoz, F.J. Functions and dysfunctions of nitric oxide in brain. Biochim. Biophys. Acta (BBA)-Mol. Basis Dis. 2019, 1865, 1949-1967. [CrossRef] 
22. Liu, H.; Manganiello, V.; Waleh, N.; Clyman, I.R. Expression, Activity, and Function of Phosphodiesterases in the Mature and Immature Ductus Arteriosus. Pediatr. Res. 2008, 64, 477-481. [CrossRef]

23. Kruuse, C.; Khurana, T.S.; Rybalkin, S.D.; Birk, S.; Engel, U.; Edvinsson, L.; Olesen, J. Phosphodiesterase 5 and effects of sildenafil on cerebral arteries of man and guinea pig. Eur. J. Pharmacol. 2005, 521, 105-114. [CrossRef]

24. Osterloh, I.H. The discovery and development of Viagra ${ }^{\circledR}$ (sildenafil citrate). In Sildenafil; Birkhäuser: Basel, Switzerland, 2004; pp. 1-13, ISBN 978-3-0348-7945-3. [CrossRef]

25. Ghofrani, H.A.; Osterloh, I.H.; Grimminger, F. Sildenafil: From angina to erectile dysfunction to pulmonary hypertension and beyond. Nat. Rev. Drug Discov. 2006, 5, 689-702. [CrossRef] [PubMed]

26. Vallejo, V.G.; Ugarte, A.; García-Barroso, C.; Cuadrado-Tejedor, M.; Szczupak, B.; Reyes, I.G.-D.; Lanciego, J.; Garcia-Osta, A.; Llop, J.; Oyarzabal, J.; et al. Pharmacokinetic investigation of sildenafil using positron emission tomography and determination of its effect on cerebrospinal fluid cGMP levels. J. Neurochem. 2015, 136, 403-415. [CrossRef] [PubMed]

27. Salloum, F.; Abbate, A.; Das, A.; Houser, J.-E.; Mudrick, C.A.; Qureshi, I.Z.; Hoke, N.N.; Roy, S.K.; Brown, W.R.; Prabhakar, S.; et al. Sildenafil (Viagra) attenuates ischemic cardiomyopathy and improves left ventricular function in mice. Am. J. Physiol. Heart Circ. Physiol. 2007, 294, H1398-H1406. [CrossRef] [PubMed]

28. Salloum, F.; Ockaili, R.; Wittkamp, M.; Marwaha, V.; Kukreja, R. Vardenafil: A novel type 5 phosphodiesterase inhibitor reduces myocardial infarct size following ischemia/reperfusion injury via opening of mitochondrial KATP channels in rabbits. J. Mol. Cell. Cardiol. 2006, 40, 405-411. [CrossRef]

29. Schwartz, B.G.; Levine, L.A.; Comstock, G.; Stecher, V.J.; Kloner, R.A. Cardiac Uses of Phosphodiesterase-5 Inhibitors. J. Am. Coll. Cardiol. 2012, 59, 9-15. [CrossRef]

30. Ding, G.; Jiang, Q.; Li, L.; Zhang, L.; Zhang, Z.; Lu, M.; Li, Q.; Gu, S.; Ewing, J.; Chopp, M. Longitudinal Magnetic Resonance Imaging of Sildenafil Treatment of Embolic Stroke in Aged Rats. Stroke 2011, 42, 3537-3541. [CrossRef] [PubMed]

31. Li, L.; Jiang, Q.; Zhang, L.; Ding, G.; Zhang, Z.G.; Li, Q.; Ewing, J.R.; Lü, M.; Panda, S.; Ledbetter, K.A.; et al. Angiogenesis and improved cerebral blood flow in the ischemic boundary area detected by MRI after administration of sildenafil to rats with embolic stroke. Brain Res. 2007, 1132, 185-192. [CrossRef] [PubMed]

32. Ding, G.; Jiang, Q.; Li, L.; Zhang, L.; Zhang, Z.G.; Ledbetter, A.K.; Panda, S.; Nejad-Davarani, S.; Athiraman, H.; Li, Q.; et al. Magnetic Resonance Imaging Investigation of Axonal Remodeling and Angiogenesis after Embolic Stroke in Sildenafil-Treated Rats. Br. J. Pharmacol. 2008, 28, 1440-1448. [CrossRef]

33. Charriaut-Marlangue, C.; Nguyen, T.; Bonnin, P.; Duy, A.P.; Leger, P.-L.; Csaba, Z.; Pansiot, J.; Bourgeois, T.; Renolleau, S.; Baud, O. Sildenafil Mediates Blood-Flow Redistribution and Neuroprotection after Neonatal Hypoxia-Ischemia. Stroke 2014, 45, 850-856. [CrossRef]

34. Ziche, M.; Morbidelli, L.; Choudhuri, R.; Zhang, H.T.; Donnini, S.; Granger, H.J.; Bicknell, R. Nitric oxide synthase lies downstream from vascular endothelial growth factor-induced but not basic fibroblast growth factor-induced angiogenesis. J. Clin. Investig. 1997, 99, 2625-2634. [CrossRef]

35. Zhang, R.; Wang, L.; Zhang, L.; Chen, J.; Zhu, Z.; Zhang, Z.; Chopp, M. Nitric Oxide Enhances Angiogenesis via the Synthesis of Vascular Endothelial Growth Factor and cGMP After Stroke in the Rat. Circ. Res. 2003, 92, 308-313. [CrossRef]

36. Morbidelli, L.; Chang, C.H.; Douglas, J.G.; Granger, H.J.; Ledda, F.; Ziche, M. Nitric oxide mediates mitogenic effect of VEGF on coronary venular endothelium. Am. J. Physiol. Circ. Physiol. 1996, 270, H411-H415. [CrossRef] [PubMed]

37. Papapetropoulos, A.; García-Cardeña, G.; Madri, A.J.; Sessa, W.C. Nitric oxide production contributes to the angiogenic properties of vascular endothelial growth factor in human endothelial cells. J. Clin. Investig. 1997, 100, 3131-3139. [CrossRef] [PubMed]

38. Fukumura, D.; Gohongi, T.; Kadambi, A.; Izumi, Y.; Ang, J.; Yun, C.-O.; Buerk, D.G.; Huang, P.L.; Jain, R.K. Predominant role of endothelial nitric oxide synthase in vascular endothelial growth factor-induced angiogenesis and vascular permeability. Proc. Natl. Acad. Sci. USA 2001, 98, 2604-2609. [CrossRef] [PubMed]

39. Pyriochou, A.; Zhou, Z.; Koika, V.; Petrou, C.; Cordopatis, P.; Sessa, W.C.; Papapetropoulos, A. The phosphodiesterase 5 inhibitor sildenafil stimulates angiogenesis through a protein kinase G/MAPK pathway. J. Cell. Physiol. 2007, 211, 197-204. [CrossRef]

40. Zhang, L.; Zhang, R.L.; Wang, Y.; Zhang, C.; Zhang, Z.G.; Meng, H.; Chopp, M. Functional Recovery in Aged and Young Rats After Embolic Stroke: Treatment with a phosphodiesterase type 5 inhibitor. Stroke 2005, 36, 847-852. [CrossRef]

41. Olivier, P.; Baud, O.; Bouslama, M.; Evrard, P.; Gressens, P.; Verney, C. Moderate growth restriction: Deleterious and protective effects on white matter damage. Neurobiol. Dis. 2007, 26, 253-263. [CrossRef]

42. Prado, J.; Pifarre, P.; Giralt, M.; Hidalgo, J.; Garcia, A. Metallothioneins I/II are involved in the neuroprotective effect of sildenafil in focal brain injury. Neurochem. Int. 2013, 62, 70-78. [CrossRef]

43. Yazdani, A.; Khoja, Z.; Johnstone, A.; Dale, L.; Rampakakis, E.; Wintermark, P. Sildenafil Improves Brain Injury Recovery following Term Neonatal Hypoxia-Ischemia in Male Rat Pups. Dev. Neurosci. 2016, 38, 251-263. [CrossRef]

44. Chen, W.; Jadhav, V.; Tang, J.; Zhang, J.H. HIF-1 $\alpha$ inhibition ameliorates neonatal brain injury in a rat pup hypoxic-ischemic model. Neurobiol. Dis. 2008, 31, 433-441. [CrossRef] [PubMed]

45. Dzietko, M.; Derugin, N.; Wendland, M.F.; Vexler, Z.S.; Ferriero, D.M. Delayed VEGF Treatment Enhances Angiogenesis and Recovery after Neonatal Focal Rodent Stroke. Transl. Stroke Res. 2013, 4, 189-200. [CrossRef]

46. Shaikh, H.; Lechpammer, M.; Jensen, F.E.; Warfield, S.K.; Hansen, A.H.; Kosaras, B.; Shevell, M.; Wintermark, P. Increased Brain Perfusion Persists over the First Month of Life in Term Asphyxiated Newborns Treated with Hypothermia: Does it Reflect Activated Angiogenesis? Transl. Stroke Res. 2015, 6, 224-233. [CrossRef] 
47. Liddelow, S.A.; Guttenplan, K.A.; Clarke, L.E.; Bennett, F.C.; Bohlen, C.J.; Schirmer, L.; Bennett, M.L.; Münch, A.E.; Chung, W.S.; Peterson, T.C.; et al. Neurotoxic reactive astrocytes are induced by activated microglia. Nature 2017, 541, 481-487. [CrossRef] [PubMed]

48. Karve, I.P.; Taylor, J.M.; Crack, P.J. The contribution of astrocytes and microglia to traumatic brain injury. Br. J. Pharmacol. 2015, 173, 692-702. [CrossRef]

49. Xu, S.; Lu, J.; Shao, A.; Zhang, J.H.; Zhang, J. Glial Cells: Role of the Immune Response in Ischemic Stroke. Front. Immunol. 2020, 11, 294. [CrossRef]

50. Jones, K.; Zouikr, I.; Patience, M.; Clarkson, A.; Isgaard, J.; Johnson, S.J.; Spratt, N.; Nilsson, M.; Walker, F.R. Chronic stress exacerbates neuronal loss associated with secondary neurodegeneration and suppresses microglial-like cells following focal motor cortex ischemia in the mouse. Brain Behav. Immun. 2015, 48, 57-67. [CrossRef]

51. Langen, K.-J.; Salber, D.; Hamacher, K.; Stoffels, G.; Reifenberger, G.; Pauleit, D.; Coenen, H.H.; Zilles, K. Detection of Secondary Thalamic Degeneration After Cortical Infarction Using cis-4-18F-Fluoro- D-Proline. J. Nucl. Med. 2007, 48, 1482-1491. [CrossRef] [PubMed]

52. Patience, M.J.; Zouikr, I.; Jones, K.; Clarkson, A.; Isgaard, J.; Johnson, S.J.; Walker, F.R.; Nilsson, M. Photothrombotic Stroke Induces Persistent Ipsilateral and Contralateral Astrogliosis in Key Cognitive Control Nuclei. Neurochem. Res. 2014, 40, 362-371. [CrossRef] [PubMed]

53. Morrison, H.W.; Filosa, J.A. A quantitative spatiotemporal analysis of microglia morphology during ischemic stroke and reperfusion. J. Neuroinflamm. 2013, 10, 4. [CrossRef] [PubMed]

54. Denés, A.; Vidyasagar, R.; Feng, J.; Narvainen, J.; McColl, B.W.; Kauppinen, R.A.; Allan, S.M. Proliferating Resident Microglia after Focal Cerebral Ischaemia in Mice. J. Cereb. Blood Flow Metab. 2007, 27, 1941-1953. [CrossRef]

55. Cheung, W.M.; Wang, C.-K.; Kuo, J.S.; Lin, T.-N. Changes in the level of glial fibrillary acidic protein (GFAP) after mild and severe focal cerebral ischemia. Chin. J. Physiol. 1999, 42, 227-235.

56. Clausen, B.H.; Lambertsen, K.L.; Babcock, A.A.; Holm, T.H.; Dagnaes-Hansen, F.; Finsen, B. Interleukin-1beta and tumor necrosis factor-alpha are expressed by different subsets of microglia and macrophages after ischemic stroke in mice. J. Neuroinflamm. 2008, 5, 46. [CrossRef]

57. Gregersen, R.; Lambertsen, K.; Finsen, B. Microglia and Macrophages Are the Major Source of Tumor Necrosis Factor in Permanent Middle Cerebral Artery Occlusion in Mice. Br. J. Pharmacol. 2000, 20, 53-65. [CrossRef]

58. Dziewulska, D.; Mossakowski, M.J. Cellular expression of tumor necrosis factor a and its receptors in human ischemic stroke. Clin. Neuropathol. 2003, 22, 35-40.

59. Nowicka, D.; Rogozinska, K.; Aleksy, M.; Witte, O.W.; Skangiel-Kramska, J. Spatiotemporal dynamics of astroglial and microglial responses after photothrombotic stroke in the rat brain. Acta Neurobiol. Exp. 2008, 68, 155-168.

60. Venkat, P.; Chopp, M.; Zacharek, A.; Cui, C.; Landschoot-Ward, J.; Qian, Y.; Chen, Z.; Chen, J. Sildenafil treatment of vascular dementia in aged rats. Neurochem. Int. 2019, 127, 103-112. [CrossRef]

61. Moretti, R.; Leger, P.-L.; Besson, V.; Csaba, Z.; Pansiot, J.; Di Criscio, L.; Gentili, A.; Titomanlio, L.; Bonnin, P.; Baud, O.; et al. Sildenafil, a cyclic GMP phosphodiesterase inhibitor, induces microglial modulation after focal ischemia in the neonatal mouse brain. J. Neuroinflamm. 2016, 13, 95. [CrossRef] [PubMed]

62. Solaroglu, I.; Gürsoy-Ozdemir, Y. Cell Death Mechanisms in Stroke and Novel Molecular and Cellular Treatment Options. Curr. Neuropharmacol. 2018, 16, 1396-1415. [CrossRef]

63. Chen, X.-M.; Wang, N.-N.; Zhang, T.-Y.; Wang, F.; Wu, C.-F.; Yang, J.-Y. Neuroprotection by Sildenafil: Neuronal Networks Potentiation in Acute Experimental Stroke. CNS Neurosci. Ther. 2013, 20, 40-49. [CrossRef] [PubMed]

64. Barros-Miñones, L.; Orejana, L.; Goñi-Allo, B.; Suquía, V.; Hervías, I.; Aguirre, N.; Puerta, E. Modulation of the ASK1-MKK3/6p38/MAPK signalling pathway mediates sildenafil protection against chemical hypoxia caused by malonate. Br. J. Pharmacol. 2013, 168, 1820-1834. [CrossRef]

65. Kilicarslan, B.; Kilicarslan, E.; Kizmazoglu, C.; Aydin, H.E.; Kaya, I.; Danyeli, A.E.; Karabekir, H.S. Evaluation of the Efficacy of Sildenafil Citrate Following Severe Head Trauma in an Experimental Rat Model. Turk. Neurosurg. 2019, 30, 501-506. [CrossRef]

66. Arvidsson, A.; Collin, T.; Kirik, D.; Kokaia, Z.; Lindvall, O. Neuronal replacement from endogenous precursors in the adult brain after stroke. Nat. Med. 2002, 8, 963-970. [CrossRef] [PubMed]

67. Parent, J.M.; Vexler, Z.S.; Gong, C.; Ma, N.D.; Ferriero, D.M. Rat forebrain neurogenesis and striatal neuron replacement after focal stroke. Ann. Neurol. 2002, 52, 802-813. [CrossRef]

68. Zhang, R.; Zhang, Z.; Wang, L.; Wang, Y.; Gousev, A.; Zhang, L.; Ho, K.-L.; Morshead, C.; Chopp, M. Activated Neural Stem Cells Contribute to Stroke-Induced Neurogenesis and Neuroblast Migration toward the Infarct Boundary in Adult Rats. Br. J. Pharmacol. 2004, 24, 441-448. [CrossRef]

69. Zhang, R.; Zhang, Z.; Zhang, C.; Zhang, L.; Robin, A.; Wang, Y.; Lu, M.; Chopp, M. Stroke Transiently Increases Subventricular Zone Cell Division from Asymmetric to Symmetric and Increases Neuronal Differentiation in the Adult Rat. J. Neurosci. 2004, 24, 5810-5815. [CrossRef]

70. Zhang, R.; Wang, Y.; Zhang, L.; Zhang, Z.; Tsang, W.; Lu, M.; Zhang, L.; Chopp, M. Sildenafil (Viagra) Induces Neurogenesis and Promotes Functional Recovery after Stroke in Rats. Stroke 2002, 33, 2675-2680. [CrossRef] [PubMed]

71. Zhang, R.L.; Chopp, M.; Roberts, C.; Wei, M.; Wang, X.; Liu, X.; Lu, M.; Zhang, Z.G. Sildenafil Enhances Neurogenesis and Oligodendrogenesis in Ischemic Brain of Middle-Aged Mouse. PLoS ONE 2012, 7, e48141. [CrossRef] 
72. Kirton, A.; DeVeber, G. Life after Perinatal Stroke. Stroke 2013, 44, 3265-3271. [CrossRef]

73. Al-Qazzaz, N.; Ali, S.H.M.; Ahmad, S.A.; Islam, S.; Mohamad, K. Cognitive impairment and memory dysfunction after a stroke diagnosis: A post-stroke memory assessment. Neuropsychiatr. Dis. Treat. 2014, 10, 1677-1691. [CrossRef] [PubMed]

74. Lutkenhoff, E.S.; Wright, M.J.; Shrestha, V.; Real, C.; McArthur, D.L.; Buitrago-Blanco, M.; Vespa, P.M.; Monti, M.M. The subcortical basis of outcome and cognitive impairment in TBI. Longitud. Cohort Study 2020, 95, e2398-e2408. [CrossRef]

75. Korzeniewski, S.J.; Slaughter-Acey, J.; Lenski, M.; Haak, P.; Paneth, N. The complex aetiology of cerebral palsy. Nat. Rev. Neurol. 2018, 14, 528-543. [CrossRef] [PubMed]

76. Wu, Y.W. Perinatal Stroke in Children with Motor Impairment: A Population-Based Study. Pediatrics 2004, 114, 612-619. [CrossRef] [PubMed]

77. Uvebrant, P. Hemiplegic cerebral palsy aetiology and outcome. Acta Paediatr. Scand. Suppl. 1988, 77, 1-100. [CrossRef] [PubMed]

78. Gorelik, N.; Faingold, R.; Daneman, A.; Epelman, M. Intraventricular hemorrhage in term neonates with hypoxic-ischemic encephalopathy: A comparison study between neonates treated with and without hypothermia. Quant. Imaging Med. Surg. 2016, 6, 504-509. [CrossRef] [PubMed]

79. Jarvis, S.; Glinianaia, S.V.; Arnaud, C.; Fauconnier, J.; Johnson, A.; McManus, V.; Topp, M.; Uvebrant, P.; Cans, C.; Krägeloh-Mann, I. Case gender and severity in cerebral palsy varies with intrauterine growth. Arch. Dis. Child. 2005, 90, 474-479. [CrossRef] [PubMed]

80. Johnston, M.V.; Hagberg, H. Sex and the pathogenesis of cerebral palsy. Dev. Med. Child Neurol. 2006, 49, 74-78. [CrossRef] [PubMed]

81. Murden, S.; Borbélyová, V.; Laštůvka, Z.; Myslivecek, J.; Otáhal, J.; Riljak, V. Gender Differences Involved in the Pathophysiology of the Perinatal Hypoxic-Ischemic Damage. Physiol. Res. 2019, 68, S207-S217. [CrossRef]

82. Covassin, T.; Schatz, P.; Swanik, C.B. Sex differences in neuropsychological function and post-concussion symptoms of concussed collegiate athletes. Neurosurgery 2007, 61, 345-351. [CrossRef] [PubMed]

83. Wasserman, E.; Kerr, Z.Y.; Zuckerman, S.L.; Covassin, T. Epidemiology of Sports-Related Concussions in National Collegiate Athletic Association Athletes from 2009-2010 to 2013-2014: Symptom Prevalence, Symptom Resolution Time, and Return-to-Play Time. Am. J. Sports Med. 2015, 44, 226-233. [CrossRef] [PubMed]

84. Sanches, E.; Arteni, N.; Nicola, F.; Boisserand, L.; Willborn, S.; Netto, C. Early hypoxia-ischemia causes hemisphere and sex-dependent cognitive impairment and histological damage. Neuroscience 2013, 237, 208-215. [CrossRef]

85. Huang, H.-Z.; Wen, X.-H.; Liu, H. Sex differences in brain MRI abnormalities and neurodevelopmental outcomes in a rat model of neonatal hypoxia-ischemia. Int. J. Neurosci. 2016, 126, 647-657. [CrossRef]

86. Mayoral, S.R.; Omar, G.; Penn, A.A. Sex Differences in a Hypoxia Model of Preterm Brain Damage. Pediatr. Res. 2009, 66, 248-253. [CrossRef] [PubMed]

87. O'Connor, C.A.; Cernak, I.; Vink, R. Interaction between Anesthesia, Gender, and Functional Outcome Task following Diffuse Traumatic Brain Injury in Rats. J. Neurotrauma 2003, 20, 533-541. [CrossRef] [PubMed]

88. Emerson, C.S.; Headrick, J.P.; Vink, R. Estrogen improves biochemical and neurologic outcome following traumatic brain injury in male rats, but not in females. Brain Res. 1993, 608, 95-100. [CrossRef]

89. Bruce-Keller, A.J.; Dimayuga, F.O.; Reed, J.L.; Wang, C.; Angers, R.; Wilson, M.E.; Dimayuga, V.M.; Scheff, S.W. Gender and Estrogen Manipulation Do Not Affect Traumatic Brain Injury in Mice. J. Neurotrauma 2007, 24, 203-215. [CrossRef] [PubMed]

90. Roof, R.L.; Duvdevani, R.; Stein, D.G. Gender influences outcome of brain injury: Progesterone plays a protective role. Brain Res. 1993, 607, 333-336. [CrossRef]

91. Roof, R.L.; Hall, E.D. Estrogen-Related Gender Difference in Survival Rate and Cortical Blood Flow after Impact-Acceleration Head Injury in Rats. J. Neurotrauma 2000, 17, 1155-1169. [CrossRef]

92. Charriaut-Marlangue, C.; Besson, V.C.; Baud, O. Sexually Dimorphic Outcomes after Neonatal Stroke and Hypoxia-Ischemia. Int. J. Mol. Sci. 2017, 19, 61. [CrossRef]

93. Ölmestig, J.N.; Marlet, I.R.; Hainsworth, A.H.; Kruuse, C. Phosphodiesterase 5 inhibition as a therapeutic target for ischemic stroke: A systematic review of preclinical studies. Cell. Signal. 2017, 38, 39-48. [CrossRef] [PubMed]

94. Tachibana, R.; Umekawa, T.; Yoshikawa, K.; Owa, T.; Magawa, S.; Furuhashi, F.; Tsuji, M.; Maki, S.; Shimada, K.; Kaneda, M.K.; et al. Tadalafil treatment in mice for preeclampsia with fetal growth restriction has neuro-benefic effects in offspring through modulating prenatal hypoxic conditions. Sci. Rep. 2019, 9, 234. [CrossRef] [PubMed]

95. Taek, K.K.; Jin, C.K.; Sae, L.H.; Gyu, K.I.; Ju, K.C.; Gil, N.Y.; Hawn, K.K. Neuroprotective effects of tadalafil on gerbil dopaminergic neurons following cerebral ischemia. Neural Regen. Res. 2013, 8, 693-701. [CrossRef]

96. Gulati, P.; Singh, N. Neuroprotective effect of tadalafil, a PDE-5 inhibitor, and its modulation by L-NAME in mouse model of ischemia-reperfusion injury. J. Surg. Res. 2014, 186, 475-483. [CrossRef] [PubMed]

97. Zhang, L.; Zhang, Z.; Zhang, R.L.; Cui, Y.; LaPointe, M.C.; Silver, B.; Chopp, M. Tadalafil, a long-acting type 5 phosphodiesterase isoenzyme inhibitor, improves neurological functional recovery in a rat model of embolic stroke. Brain Res. 2006, 1118, 192-198. [CrossRef]

98. Gulati, P.; Singh, N. Tadalafil enhances the neuroprotective effects of ischemic postconditioning in mice, probably in a nitric oxide associated manner. Can. J. Physiol. Pharmacol. 2014, 92, 418-426. [CrossRef] 
99. Ko, I.-G.; Shin, M.-S.; Kim, B.-K.; Kim, S.-E.; Sung, Y.-H.; Kim, T.-S.; Shin, M.-C.; Cho, H.-J.; Kim, S.-C.; Kim, S.H.; et al. Tadalafil improves short-term memory by suppressing ischemia-induced apoptosis of hippocampal neuronal cells in gerbils. Pharmacol. Biochem. Behav. 2009, 91, 629-635. [CrossRef]

100. Gao, F.; Sugita, M.; Nukui, H. Phosphodiesterase 5 inhibitor, zaprinast, selectively increases cerebral blood flow in the ischemic penumbra in the rat brain. Neurol. Res. 2005, 27, 638-643. [CrossRef]

101. Chen, X.; Wang, N.; Liu, Y.; Liu, Y.; Zhang, T.; Zhu, L.; Wang, Y.; Wu, C.; Yang, J. Yonkenafil: A novel phosphodiesterase type 5 inhibitor induces neuronal network potentiation by a cGMP-dependent Nogo-R axis in acute experimental stroke. Exp. Neurol. 2014, 261, 267-277. [CrossRef]

102. Iskar, M.; Zeller, G.; Blattmann, P.; Campillos, M.; Kuhn, M.; Kaminska, K.H.; Runz, H.; Gavin, A.-C.; Pepperkok, R.; van Noort, V.; et al. Characterization of drug-induced transcriptional modules: Towards drug repositioning and functional understanding. Mol. Syst. Biol. 2013, 9, 662. [CrossRef]

103. Taniguchi, Y.; Tonai-Kachi, H.; Shinjo, K. Zaprinast, a well-known cyclic guanosine monophosphate-specific phosphodiesterase inhibitor, is an agonist for GPR35. FEBS Lett. 2006, 580, 5003-5008. [CrossRef] [PubMed]

104. Cosi, C.; Mannaioni, G.; Cozzi, A.; Carlà, V.; Sili, M.; Cavone, L.; Maratea, D.; Moroni, F. G-protein coupled receptor 35 (GPR35) activation and inflammatory pain: Studies on the antinociceptive effects of kynurenic acid and zaprinast. Neuropharmacology 2011, 60, 1227-1231. [CrossRef] [PubMed]

105. Ekker, M.S.; Boot, E.M.; Singhal, A.B.; Tan, K.S.; Debette, S.; Tuladhar, A.M.; de Leeuw, F.-E. Epidemiology, aetiology, and management of ischaemic stroke in young adults. Lancet Neurol. 2018, 17, 790-801. [CrossRef]

106. Dewan, M.C.; Rattani, A.; Gupta, S.; Baticulon, R.E.; Hung, Y.-C.; Punchak, M.; Agrawal, A.; Adeleye, A.O.; Shrime, M.G.; Rubiano, A.M.; et al. Estimating the global incidence of traumatic brain injury. J. Neurosurg. 2019, 130, 1080-1097. [CrossRef] [PubMed]

107. George, M.G.; Tong, X.; Bowman, B.A. Prevalence of Cardiovascular Risk Factors and Strokes in Younger Adults. JAMA Neurol. 2017, 74, 695-703. [CrossRef]

108. Bramlett, H.M.; Dietrich, W.D. Pathophysiology of Cerebral Ischemia and Brain Trauma: Similarities and Differences. Br. J. Pharmacol. 2004, 24, 133-150. [CrossRef] [PubMed]

109. Bandera, E.; Botteri, M.; Minelli, C.; Sutton, A.; Abrams, K.; Latronico, N. Cerebral Blood Flow Threshold of Ischemic Penumbra and Infarct Core in Acute Ischemic Stroke. Stroke 2006, 37, 1334-1339. [CrossRef]

110. Rostami, E.; Nilsson, P.; Enblad, P. Cerebral Blood Flow Measurement in Healthy Children and Children Suffering Severe Traumatic Brain Injury-What Do We Know? Front. Neurol. 2020, 11, 274. [CrossRef]

111. Ng, S.Y.; Lee, A.Y.W. Traumatic Brain Injuries: Pathophysiology and Potential Therapeutic Targets. Front. Cell. Neurosci. 2019, 13, 528. [CrossRef]

112. Kaur, P.; Sharma, S. Recent Advances in Pathophysiology of Traumatic Brain Injury. Curr. Neuropharmacol. 2018, 16, 1224-1238. [CrossRef]

113. Rostami, E.; Engquist, H.; Enblad, P. Imaging of Cerebral Blood Flow in Patients with Severe Traumatic Brain Injury in the Neurointensive Care. Front. Neurol. 2014, 5, 114. [CrossRef] [PubMed]

114. Marion, D.; Darby, J.; Yonas, H. Acute regional cerebral blood flow changes caused by severe head injuries. J. Neurosurg. 1991, 74, 407-414. [CrossRef] [PubMed]

115. Adelson, D.; Clyde, B.; Kochanek, P.; Wisniewski, S.; Marion, D.; Yonas, H. Cerebrovascular Response in Infants and Young Children following Severe Traumatic Brain Injury: A Preliminary Report. Pediatr. Neurosurg. 1997, 26, 200-207. [CrossRef]

116. Adelson, P.D.; Srinivas, R.; Chang, Y.; Bell, M.; Kochanek, P.M. Cerebrovascular response in children following severe traumatic brain injury. Child's Nerv. Syst. 2011, 27, 1465-1476. [CrossRef] [PubMed]

117. Allen, K.A.; Brandon, D.H. Hypoxic Ischemic Encephalopathy: Pathophysiology and Experimental Treatments. Newborn Infant Nurs. Rev. 2011, 11, 125-133. [CrossRef]

118. Adén, U. Neonatal Stroke Is Not a Harmless Condition. Stroke 2009, 40, 1948-1949. [CrossRef]

119. Nelson, K.B. Perinatal Ischemic Stroke. Stroke 2007, 38, 742-745. [CrossRef]

120. Fernández-López, D.; Natarajan, N.; Ashwal, S.; Vexler, Z.S. Mechanisms of Perinatal Arterial Ischemic Stroke. Br. J. Pharmacol. 2014, 34, 921-932. [CrossRef] [PubMed]

121. Lynch, J.K.; Nelson, K.B. Epidemiology of perinatal stroke. Curr. Opin. Pediatr. 2001, 13, 499-505. [CrossRef] [PubMed]

122. Raju, T.N.; Nelson, K.B.; Ferriero, D.; Lynch, J.K. Ischemic Perinatal Stroke: Summary of a Workshop Sponsored by the National Institute of Child Health and Human Development and the National Institute of Neurological Disorders and Stroke. Pediatrics 2007, 120, 609-616. [CrossRef]

123. Back, S.A.; Rivkees, S.A. Emerging concepts in periventricular white matter injury. Semin. Perinatol. 2004, 28, 405-414. [CrossRef] [PubMed]

124. McQuillen, P.; Ferriero, D.M. Selective vulnerability in the developing central nervous system. Pediatr. Neurol. 2004, 30, 227-235. [CrossRef]

125. Volpe, J.J. Brain injury in premature infants: A complex amalgam of destructive and developmental disturbances. Lancet Neurol. 2009, 8, 110-124. [CrossRef]

126. Elbers, J.; Viero, S.; MacGregor, D.; DeVeber, G.; Moore, A.M. Placental Pathology in Neonatal Stroke. Pediatrics 2011, 127, e722-e729. [CrossRef] [PubMed] 
127. Kraus, F.T. Cerebral palsy and thrombi in placental vessels of the fetus: Insights from litigation. Hum. Pathol. 1997, 28, 246-248. [CrossRef]

128. Kraus, F.T.; Acheen, I.V. Fetal thrombotic vasculopathy in the placenta: Cerebral thrombi and infarcts, coagulopathies, and cerebral palsy. Hum. Pathol. 1999, 30, 759-769. [CrossRef]

129. Long, M.; Brandon, D.H. Induced Hypothermia for Neonates with Hypoxic-Ischemic Encephalopathy. J. Obstet. Gynecol. Neonatal Nurs. 2007, 36, 293-298. [CrossRef] [PubMed]

130. Cotten, C.M.; Shankaran, S. Hypothermia for hypoxic-ischemic encephalopathy. Expert Rev. Obstet. Gynecol. 2010, 5, 227-239. [CrossRef] [PubMed]

131. Shalak, L.; Perlman, J.M. Hypoxic-ischemic brain injury in the term infant-current concepts. Early Hum. Dev. 2004, 80, 125-141. [CrossRef] [PubMed]

132. Kenney, K.; Amyot, F.; Moore, C.; Haber, M.; Turtzo, L.C.; Shenouda, C.; Silverman, E.; Gong, Y.; Qu, B.-X.; Harburg, L.; et al. Phosphodiesterase-5 inhibition potentiates cerebrovascular reactivity in chronic traumatic brain injury. Ann. Clin. Transl. Neurol. 2018, 5, 418-428. [CrossRef] [PubMed] 